\title{
LOS PROBLEMAS DEL INCIDENTE DE DESACATO
}

La acción de tutela es el mecanismo constitucional más utilizado y con mayor arraigo entre los colombianos. Esta acción, consagrada en el artículo 86 de la Constitución Política Colombiana de 1991, busca la protección por vía judicial de los derechos constitucionales fundamentales de los ciudadanos, ante la eminente 0 actual vulneración por parte de un particular o del mismo Estado colombiano. El proceso, que debe ser tramitado en un término perentorio de 10 días improrrogables por parte de un juez de la República, debe culminar con una decisión judicial de primera instancia, la cual admite impugnación ante el superior jerárquico del juez. La decisión del juez de segunda de instancia debe ser proferida en un plazo máximo de 20 días.

La normativa de la tutela establece un procedimiento adicional para obligar al acatamiento de la orden judicial en caso de que el tutelado no cumpla la orden. Esta herramienta llamada "incidente de desacato" puede ser iniciada por el afectado por el incumplimiento del derecho fundamental.

Su finalidad es lograr el acatamiento inmediato de la orden impartida por el juez, con la amenaza de una sanción (arresto o multa) al servidor público o al particular que haya vulnerado o se encuentren en curso de una vulneración de derechos constitucionales fundamentales y que, ante la orden de protección emanada del juez en una sentencia de tutela, se muestren renuentes a su cumplimiento.

Inicialmente en los primeros años de vigencia de la tutela, el desacato se mostró como una herramienta útil para obligar al cumplimiento del fallo judicial. Sin embargo, desde hace algunos años ni siquiera con una amenaza de arresto o multa por parte de un juez, los tutelados cumplen la orden judicial.

Es así como en muchos procesos de tutela se verifica una demora en el acatamiento de la orden judicial por parte del tutelado, quien dilata su cumplimiento tal vez con la esperanza de lograr zafarse de la obligación de cumplir la orden, principalmente en los procesos en que la orden conlleva altos costos financieros, como son los casos de las tutelas en el sector salud.

En la sentencia de la Corte Constitucional T-606 de 2011, el alto tribunal reiteró que el trámite de cumplimiento y el incidente de desacato son los medios idóneos y eficaces para hacer cumplir los fallos de tutela. En esta decisión la Corte fijó 4 etapas del incidente:

a) Comunicar a la persona incumplida la apertura del incidente, para que pueda dar cuenta de la razón por la que no cumplió y presente sus argumentos de defensa. 
b) Practicar las pruebas solicitadas que sean conducentes y pertinentes con la decisión.

c) Notificar la providencia que resuelva el incidente.

d) Remitir el expediente en consulta al superior.

No obstante, en la práctica judicial se denuncia frecuentemente que estas etapas se alargan en el tiempo con lo cual la orden de tutela no es cumplida en forma inmediata sino muchos días -o meses- después, ocasionándose en muchos casos la consumación de la vulneración del derecho.

Para tratar de solucionar este vacío legal, el Senado aprobó en segundo debate el texto definitivo de una iniciativa (P. L. 053/16S, 23/05/17), con la cual se modificaría el artículo 52 del Decreto 2591 de 1991, estableciendo el término legal para resolver el incidente de desacato.

La iniciativa establecía un término de hasta 10 días para decidir el incidente de desacato. Sin embargo, dicha iniciativa no tuvo feliz término por lo que aún subsiste el vacío legal.

Se hace imperiosa una reglamentación normativa que coloque límites mas cortos al trámite de tutela y se sancione eficazmente a quienes burlan las órdenes judiciales. Mientras no se hagan estos ajustes, las ordenes de los jueces podrán seguir burladas.

Germán Alfonso López Daza (PhD). Editor Revista Jurídica Piélagus 